\title{
Conditions for Multi-ethnic Coexistence in Lithuania \\ リトアニアにおける複数民族共存の条件
}

\begin{abstract}
はじめに
本稿は微視的制度研究の方法論にもとづいて、 リトアニアにおける複数民族共存の条件を考察す ることにより、東欧における体制移行の外的環境 (所与の環境)のうち最も重要な要因のひとつであ る民族問題を分析する一視点を提示するものであ る。
\end{abstract}

筆者は平成 8 年度と平成 9 年度において、文部省 科学研究費 (国際学術研究) の交付を受け、リトア ニアのビリュニュース県を中心に調査を行った。 本論文はその調査にもとづくものである。研究代 表者は筆者であり、研究分担者として早坂真理氏 (東京工業大学)、Laimute Zilinskiene氏 (ビリュニ ュース大学)、Stanislaw Majewski氏 (ビリュニュー ス・ポーランド大学)、Stanislaw Hejbowicz氏 (ビリ ユニュース農業高等専門学校)が参加した。なお、 本稿は、筆者が担当した調査部分にのみ基いてい る。早坂真理氏担当の部分については、早坂氏に よって別途発表の予定である。

調査の目的は、複数民族が共存するリトアニア・ ビリュニュース県において、複数民族社会におけ る社会的協調過程がどのように形成されているか を確認することにあった。

\section{1.調査の概要}

調査の概要と基本方針は以下のようなものであ つた。

ア)リトアニアにおいて、複数民族状況が最も顕著 な県であるビリュニュース県を調査対象県として選 定した。また、この県を選定した理由として、筆者 が比較的自由に話せるポーランド語で調査ができ ることも重要な要因であった。

イ)ビリュニュース県の中で、P村が調查対象として 選定された。P村は村内にリトアニア人集落、ポー ランド人集落、タタール人集落などを抱える複数民

\section{北海道大学吉 野 悦 雄}

族地域である。ビリュニュース県には複数民族地 域は多数あるが、研究分担者の知り合いが村長を つとめるP村が選定された。

ウ) $\mathrm{P}$ 村の中から、ポーランド人集落であるM部落、 タタール人 (イスラム教徒) 集落であるS 部落が選ば れ、また隣県のT部落がリトアニア人集落として選 ばれた。

エ)ひとつの集落の中では、原則として全数調査の 方針を採った。M部落の場合でいえば、35戸前後 の家屋からなるが、その中で12戸の家族と面談を 行った。しかし、通常は1戸の面談において、同じ 部落の中に住む両親・兄弟などの親戚が参加する ため、1回の面談で2戸ないし3戸の調査が行われ たことになる。したがって12回の面談で、部落のほ ぼ7割ないし8割の家族の実態が掌握できたと考え ている。

オ）一方、ロシア人家族、ベラルーシ人家族につい ては、それらがまとまって居住するロシア人集落・ ベラルーシ人集落というものはビリュニュース県に はなく、したがって、いくつかの集落から調查対象 を抜粋して調査を行うことになった。抜粋の基準 は、現地の研究分担者の紹介によった。所得水準 や経歴などは様々であったので、紹介の基準にあ る種の偏りがあったとは考えていない。

力)これ以外にユダヤ人、ドイツ人、カライム人 (ユ ダヤ教とイスラム教の双方の影響を受けている極 小の少数民族）の3家族を県外から選定し面接調查 を行った。ポーランド人家族 12 戸、リトアニア人家 族 8 戸、タタール人家族 9 戸、ロシア人家族とベラル 一シ人家族を合わせて13戸の調査を行っているの で、合計で45戸の調査であった。

キ) 1 戸あたりの調査時間は平均して 6 時間である。 うち4時間を面接調査にあて、会話のすべてをテー プレコーダーに録音した。表面的かつ誘導的な質 問条項は、先祖にさかのぼる家系図にかかわるこ 
とと、本人のライフ・ヒストリー(生活史)にかかわる ことである。これらの事項を聞き出す中で、複数 民族問題の手掛かりをつかもうという方針であっ た。しかしより根本的な方針は、本人が話したい ことを話してもらおうというものであり、家系罒や 生活史に関する質問は単なる「呼び水」の役割を 果たしたにすぎない。本人が自発的に話した内容 の中から複数民族問題の諸要因を採集することを 基本的方針とした。

ク) 質問者がアジアからの外国人 (筆者)であるの

で、被調査者はかなりフランクに私的な人生を語っ てくれた。この利点を生かすため、現地の研究分 担者はできるだけ表面には出ないようにした。ま た通訳は用いなかった。

\section{2.研究方法論 : 微視的制度研究}

この調查は微視的制度研究の方法論に基づいて 行われた。この方法論については広く知られてい るとは言えないが、既に日本語の論文（吉野1998） とポーランド語の著作 $(Y o s h i n o, 1997)$ においてそ の詳細を明らかにしているので、ここではその要点 だけを簡単に紹介しよう。なお、この方法論を用 いた具体的成果は、日本語では文献 (吉野1993)が 公刊されている。

第一の特徵は、C.Ginzburg (1966および1976)の ミクロストーリア手法と同様に、極めて微少な対象 を研究することにより、社会全体を個から逆照射し て考察するという立場である。ギンズブルグ (1976) は、16世紀イタリア北部の一人の粉挽き小屋の主 人の一生を詳細に調べて中せの終焉に迫った。本 調査はリトアニアの45戸の家族の歴史からリトアニ ア複数民族社会の特質を抽出しようとした。

第三の特徽は、C.Geertz (1973) の濃密叙述 (thick desciption) 手法にみられるように、観祭対 象を濃密に叙述して分析するという立場である。 この手法の代表例はO.Lewis (1961) であり、ルイス はメキシコ・シティーのスラムに住むサンチェス家 で数百時間のインタビューを録音し分析を行った。 筆者の調査は、一戸あたり平均6時間の面接であ ったから、濃密性においてルイスに少るが、方法
論としてはギアツとルイスから大きな影響を受けて いる。

第三の特徵は、第二の特徴の当然の帰結として、 分析が多角的かつ総合的になるということである。 具体的には社会学的・経済学的. 法学的・歴史学 的・人類学的な分析視覚が総合される。

第四の特徴は、口述史 (oral history) や回想録を 用いることにより生活史 (life history) の解析に重 点が置かれていることである。生活史研究の嗃矢 はF.Znaniecki (1918-1920)であり、ズナニェツキ はポーランドから北米と欧州に移民した50家族が 書いた764本の手紙を収集し分析を行った。筆者 の調査では直接インタビューにより、家系困の作成 を中心に生活史を再構成した。

第五の特徴は、観察 (調査) 段階で、分析モデル の導入を否定することである。すなわち調査段階 でのモデルや仮説の設定を否定し、調査によって 得られた情報の分析段階でモデルや仮説を導入し ようとするものである。この特徴は具体的には民 族の確定方法などにあらわれているので、次節で 説明しよう。

\section{3.民族の確定}

住民がどの民族であるかを確定する方法には以 下の4種類があろう。

（1）被調查者の主観。自分が何人であると考えて いるか、に応じて民族を確定する。しかし、この主 観を被調査者が常に素直に語ってくれるとは限ら ない。また、ふだんから、自分が何人であるかを深 く考えていない例すらある。

(2) 調查者の主観。調查者が保持する民族概念に 応じて調査者が民族を分類する。すなわち調査者 が設定するモデルや仮説に応じて民族を分類す る。しかし、筆者の経験においては、調查を夷施 する段階になって、調査設計段階の仮説を放棄せ ざるを得なくなることが多い。今回の調査の例でい えばべラルーシ人とは何かについて、日本国内の 文献で得ていた概念は適用できなかった。今回の 調査では、面接段階では相手がロシア人であるの かベラルーシ人であるのかポーランド人であるの 
かについて予断を持たずに調査を行った。

（3）当人をとりまく社会関係のなかで受容されてい る民族概念によって民族を分類する。すなわち、 社会の中で当人が何人として扱われているかに応 じて民族を分類する。この場合、必ずしも本人の 主観 (秘めたる自己意識)と一致するとは限らない。 （4）法的規範ないし統計的規範に応じて分類する。 日本の「旧土人法」や、1945年のポーランドにおけ る強制退去対象のドイツ人を定める法令などのよ うに法令により民族概念が規定されている場合が ある。また国勢調査を実施する中央統計局は調査 マニュアルを作成することにより統計的規範を決 定している。これらの法的規範や統計処理規範に 応じて民族を分類する。しかし、この方法は社会 調査では極めて不適当である。リトアニアの例で言 えば、18歳未満の混血の場合、社会主義時代は父 親の民族に応じて子供の民族分類が決まっていた が、社会主義崩壊後は母親の民族に応じて子供の 民族分類が決まるようになった。国勢調查ではこ のような規範を設ける必要があろうが、社会分析 では不適切であることは言をまたない。

本調査では上記の (3)を採用した。すなわち仮 説や予断を持たずに面接を行い、それによって再 構成された家系罒と生活史の中で、当人が何人と して扱われているかにより民族を確定した。特殊 な事例として、1950年代ではべラルーシ人として扱 われ、1960年代以降はポーランド人として扱われた 人もいたが、調查時点における当人の社会の中で の扱われ方、ないし死亡時点における当人の社会 の中での扱われ方に応じて、筆者は民族を分類し た。

\section{4.マクロ統計データからみた民族構成}

前節で述べたように、統計的規範は社会分析に おいて必ずしも適切なものとはいえない。それに もかかわらず、全国レベルでの趨勢をみるために はマクロ統計データしか依拠するものがないので、 表1において過去140年間の民族構成データを紹介 しよう。

表1は、現在のリトアニアの領土に相当する地域
における民族構成を示す。いうまでもなく、第一次 世界大戦以前は、現リトアニアのバルト海沿岸地域 はプロシャ領であり、その他の地域はロシア帝国 領であった。両大戦間期においては、バルト海沿 岸地域はドイツ領であり、東部と南部の一部はポ 一ランド領であった。それゆえ、戦前期において はドイツ人比率が高く、また両大戦間期においては ポーランド人比率が高い。1945年以降、これらの 人々のうちかなりの部分が祖国に引き揚げた。一 方ロシア人とベラルーシ人については、前世紀に おいてはその比率が極めて小さく、1945年以降の 社会主義化の時代に大量の人口流入があったこと が見てとれる。ユダヤ人については、今次大戦に おけるナチスによるホロコーストと東方への避難に より人口が激減し、1970年代においてもイスラエル への移住があったためユダヤ人人口は激減した。 タタール人については前世紀から圧倒的な少数民 族であった。

では、このような全国レベルでのマクロ統計デ 一タがどれだけの意味を持つのかを検討しよう。 表 2 はビリュニュース県 (首都ビリュニュース市 は含まず、同市をドーナツ型に囲む県である)とそ の周辺5県の国勢調査データが示されている。表 2 から明らかなように、県ごとに民族構成は大きく異 なり、社会分析のデータとしては全国統計が意味を 持たないことが理解されよう。

さらに表 2 はバレナ県の中の $2 つ の$ 村のデータも 紹介してあるが、リトアニア人が圧倒的多数民族で あるバレナ県においても、ポーランド人が圧倒的多

\section{表 1 リトアニア全土における民族構成}

（現在のリトアニアの領土に対応する地域に居住していた民族の 構成。単位は\%)

\begin{tabular}{|l|rrrrr|}
\hline & 1857 年 & 1923 年 & 1959 年 & 1979 年 & 1989 年 \\
\hline リトアニア人 & 75.6 & 69.2 & 79.3 & 80.0 & 79.6 \\
ロシア人 & 1.4 & 2.5 & 8.5 & 8.9 & 9.4 \\
ポーランド人 & 5.6 & 15.3 & 8.5 & 7.3 & 7.0 \\
ベラルーシ人 & 0.3 & 0.4 & 1.1 & 1.7 & 1.7 \\
ウクライナ人 & 0.1 & 0.0 & 0.7 & 0.9 & 0.2 \\
ユダヤ人 & 10.7 & 8.3 & 0.9 & 0.4 & 1.3 \\
ラトビア人 & 1.0 & 0.6 & 0.2 & 0.1 & 0.1 \\
タタール人 & 0.1 & 0.1 & 0.1 & 0.1 & 0.1 \\
ジプシー & 0.0 & 0.0 & 0.1 & 0.1 & 0.1 \\
ドイツ人 & 5.1 & 3.4 & 0.4 & 0.1 & 0.1 \\
その他の民族 & 0.1 & 0.2 & 0.2 & 0.4 & 0.4 \\
\hline
\end{tabular}

出所:Grzegorz Blaszczyk: Litwa Wspolczesna. PWN. 1992. s. 70 
表2 ビリュニュース市の周辺の県における人種構成（\%)

\begin{tabular}{|c|c|c|c|c|c|}
\hline & リトアニア人 & ロシア人 & ポーランド人 & ベラルーシ人 & その他 \\
\hline ビリュニュース県 (ビリュニュース市を取り囲む賑村部の & & & & & \\
\hline 地帯。ドーナツ师で穴の部分はビリュニュース市) & 20.8 & 9.1 & 63.5 & 4.7 & 1.9 \\
\hline Ignalina県（ビリュニュース市の北方） & 39.2 & 39.7 & 7.5 & 7.5 & 6.4 \\
\hline Salcininkai県（ビリュニュース市の南方） & 9.4 & 5.8 & 79.6 & 3.8 & 1.4 \\
\hline Svencionys県（ビリュニュース市の北方） & 47.4 & 16.2 & 28.8 & 5.5 & 2.1 \\
\hline Trakai県（ビリュニュース市の東方） & 57.6 & 11.9 & 23.8 & 4.1 & 2.6 \\
\hline Varena県（ビリュニュース市の南西方向） & 89.9 & 1.5 & 7.0 & 1.1 & 0.5 \\
\hline 同県Eisiskes村 & 2.9 & 1.5 & 93.5 & 0.9 & 1.2 \\
\hline 同県Turmantas村 & 16.7 & 31.5 & 45.6 & 4.5 & 1.7 \\
\hline
\end{tabular}

出所：1989年国染調查による

数民族である村もあり、またポーランド人とロシア 人が拮抗していてリトアニア人が少数民族である 村もあることが分かる。

さらに、今回の調査からも分かるように、同じ村 の中であっても、ポーランド人だけが居住する部落 もあり、タタール人が集中的に居住している部落も ある。集落レべルでみると、全国的には少数民族 であるタタール人が多数民族となっている部落も 存在するのである。ここに、ミクロレベルから複数 民族問題を考察する必然性が存在する。

\section{5.マクロ的民族概念の規定要因：宗教と言語}

表1における1923年のデータがどのような統計的 規範に基づいて算定されたのかは全く不明であ る。1921年にポーランドで行われた国勢調査では、 住民の自己申告を基本としながら、部落長などの 国勢調査員が自己判断で民族欄を記入したといわ れている。では当時のマクロ的な民族規定要因は 何であったのだろうか。表3は1923年におけるリト アニア全土の宗教構成を示している。表3と表1の 1923年のデータを比較すると、リトアニア人の一部 がプロテスタントを信仰していたので、ドイツ人人 口をかなり上回るプロテスタント信者が存在してお り、その上乗せ分だけ、ポーランド人人口とリトアニ ア人人口の合計よりもローマ・カトリック信者が少 なくなっている。一方、ヘブライ教信者の数よりも ユダヤ人人口の数の方が多いから、表1の民族統 計規範が宗教でないことは明らかである。

では表1の民族統計規範は言語であったのだろ うか。表4は1931年に実施されたポーランド国勢調 査におけるビリュニュース県 (ポーランドの当時の 行政区分)のデータを示す。なお当時の行政区分
のビリュニュース県のうち、その東半分は現在はべ ラルーシ領であり、西半分は現在のリトアニア領と なっている。西半分は現在のビリュニュース市を とりまく4県に相当すると考えてよい。全体的傾向 としては言語と宗教に強い相関関係が存在する。 ヘブライ教信者数とユダヤ人言語であるイーディッ シュ語とへブライ語の使用者数はほぼ一致する。 しかし既に述べたように、ユダヤ人人口はへブラ イ教信者数よりも多い。これは一部のユダヤ人が ヘブライ教を棄教し、使用言語もポーランド語に変

表3 1923年時点におけるリトアニア全土の宗教構成

(数値は絶対数と\%)

\begin{tabular}{|l|rc|}
\hline & \multicolumn{1}{|c|}{ 絶対数 } & 構成比 \\
\hline カトリック & 1.746 .942 & 80.5 \\
プロテスタント & 207.118 & 9.5 \\
ヘブライ教 & 157.527 & 7.3 \\
ロシア正教 & 55.122 & 2.5 \\
その他のキリスト教 & 1.889 & 0.1 \\
その他の非キリスト教 & 1.640 & 0.1 \\
宗派不明 & 378 & 0.0 \\
\hline
\end{tabular}

（注「その他の非キリスト教」とはイスラム教とカライム教を指す 出所: Grzegorz Blaszczyk: Litwa Wspolczesna, PWN. 1992. s. 70

えていたためであるが、表1のマクロ統計では、こ のような彼らもユダヤ人として扱われていることに なる。

このように言語もまた民族統計の規範ではなか った。ポーランド国勢調査からの類推になるが、リ トアニアにおいても社会的にどのような民族として 受容されているかを統計調査員が判断して民族分 類が行われたと想定される。ここに、ミクロ・レべ ルから社会関係と家族関係を再構成して複数民族 問題を考察する必要性が生まれる。 
表4 1931年ポーランド国勢調査におけるビリュニュース県の町部と村部での宗教と言語の構成(\%)

\begin{tabular}{|c|c|c|c|c|c|c|c|c|c|c|}
\hline \multirow{2}{*}{$\begin{array}{l}\text { ビリュニュー } \\
\text { ス県町部 }\end{array}$} & 言語 & $\begin{array}{l}\text { ポーラ } \\
\text { ンド語 } \\
63.0\end{array}$ & $\begin{array}{c}\text { ククラ } \\
\text { イナ語 } \\
0.1\end{array}$ & $\begin{array}{l}\text { ベラル } \\
\text { 一シ語 } \\
3.0\end{array}$ & $\begin{array}{l}\text { ロシア } \\
\text { 語 } \\
\quad 3.7\end{array}$ & $\begin{array}{l}\text { ドイツ } \\
\text { 語 } \\
0.2\end{array}$ & $\begin{array}{c}\text { イーディッシュ語 } \\
\text { またはへブライ語 } \\
28.9\end{array}$ & \multicolumn{3}{|c|}{$\begin{array}{c}\text { その他の言語 } \\
1.1\end{array}$} \\
\hline & 宗教 & $\begin{array}{l}\text { カトリッ } \\
\text { ク } \\
60.8\end{array}$ & $\begin{array}{l}\text { ギリシャ } \\
\text { 正教 } \\
0.1\end{array}$ & \multicolumn{2}{|c|}{$\begin{array}{c}\text { ロシア正教 } \\
7.5\end{array}$} & $\begin{array}{l}\text { ルター } \\
\text { 派 } \\
\quad 0.8\end{array}$ & $\begin{array}{c}\text { ユダヤ教 } \\
29.2\end{array}$ & $\begin{array}{c}\text { その他の } \\
\text { キリスト教 } \\
1.1\end{array}$ & $\begin{array}{l}\text { 非キリ } \\
\text { スト教 } \\
0.4\end{array}$ & $\begin{array}{c}\text { その他 } \\
0.1\end{array}$ \\
\hline \multirow{2}{*}{$\begin{array}{l}\text { ビリュニュー } \\
\text { ス県村部 }\end{array}$} & 言語 & $\begin{array}{l}\text { ポーラ } \\
\text { ンド語 } \\
58.8\end{array}$ & $\begin{array}{l}\text { ウクラ } \\
\text { イナ語 } \\
0.0\end{array}$ & $\begin{array}{r}\text { ベラル } \\
\text { ージ語 } \\
27.8\end{array}$ & $\begin{array}{l}\text { ロシア } \\
\text { 語 } \\
3.3\end{array}$ & $\begin{array}{l}\text { ドイツ } \\
\text { 語 } \\
0.1\end{array}$ & $\begin{array}{c}\text { イーディッシュ語 } \\
\text { またはヘブライ語 } \\
3.3\end{array}$ & \multicolumn{3}{|c|}{$\begin{array}{c}\text { その他の言語 } \\
6.6\end{array}$} \\
\hline & 宗教 & $\begin{array}{l}\text { カトリッ } \\
\text { ク } \\
62.9\end{array}$ & $\begin{array}{l}\text { ギリシャ } \\
\text { 正教 } \\
0.1\end{array}$ & \multicolumn{2}{|c|}{$\begin{array}{c}\text { ロシア正教 } \\
30.1\end{array}$} & $\begin{array}{l}\text { ルター } \\
\text { 派 } \\
0.1\end{array}$ & $\begin{array}{c}\text { ユダヤ教 } \\
3.4\end{array}$ & $\begin{array}{l}\text { その他の } \\
\text { キリスト教 } \\
\text { 3.1 }\end{array}$ & $\begin{array}{l}\text { 非キリ } \\
\text { スト教 } \\
0.2\end{array}$ & $\begin{array}{c}\text { その他 } \\
0.1\end{array}$ \\
\hline
\end{tabular}

（注1）当時のポーランドの行政区であるビリュニュース県の東半分は現在ではベラルーシ領に含まれる。西半分は現在ではリトアニア領に含まれ、ビリ ユニュース市とその周辺4県に該当する。

(注2）イーディッシュ語とは、東欧地域に居住していたユダヤ人の使用言語。ヘブライ語とは全く異なる。

(注3）「その他のキリスト教」とは主にカルバン派とエホバの証人を指すと思われる。

(注4)「非キリスト教」とはイスラム教とカライム教を指す。

（注5）「その他の言語」とは主にリトアニア語を指すと思われる。

出所 : Glowny Urzad Statystyczny. Maly Rocznik Statystyczny 1939. Warszawa. 1939. s. 23. 25.

\section{6.婚姻関係の形成と民族の融合}

本調査の45戸の家系図から、婚姻関係の形成の 基本的影響要因は宗教であることが明確となった。 民族の規定諸要因のうち宗教が最も強く婚姻関係 に影響を及ぼしていた。

最も特徵的な例は整理番号 46 番のユダヤ人の家 庭である。紙幅の都合上、本論文では家系図を紹 介できないが、この家系図には46人が登場する。 そのうち、ユダヤ人以外の者は 2 人だけである。そ れ以外はすべてへブライ教徒同士で婚姻関係が成 立している。複数民族社会にあって、極めて強固 な民族固定性であるといえよう。しかし、被調査者 自身が述べるように、へブライ教が形骸化している 若い世代においては他の民族との婚姻例が多くな っているという。

整理番号 23 番のリトアニア人家庭においても、強 固な民族固定性が観察される。この家系図には41 人の人物が登場するが、リトアニア人以外の要因が みられるのは、一人だけである。この農家はリトア ニア人だけが居住するT部落の住民であり、このよ うな単一民族部落にあっては、たとえ社会全体が 複数民族社会であっても、婚姻関係は同一民族内 だけで成立する傾向があることが観察された。

しかし、この例は、リトアニアにおける最大多数 民族であるリトアニア人の例であるということに留 意しなければならないだろう。少数民族であるポ
ーランド人の場合はどうであろうか。ポーランド人 部落に住む整理番号 5 番のポーランド人家庭の場合 では子供 2 人はリトアニア人と結婚しており、孫は リトアニア語小学校に通った後、職場でもリトアニ ア人として扱われている。「リトアニア化」の典型例 である。ただしここで、ポーランド人もリトアニア人 も共にカトリックである点に留意しなければならな い。結婚に際して宗教上の障害は全く存在しない。 ポーランド人よりもさらに少数民族であるロシア 人の場合はどうであろうか。ロシア人には 2 種類が あり、17世紀以来、ロシア正教の改革運動に反対 して古いロシア正教を守ったが故にロシアを追放 され当地に移住してきたロシア正教守旧派のcraрообрядец (starowierca) と呼ばれるグループと、 特に戦後の社会主義化時代にロシアやベラルーシ から移住してきたロシア正教正統派のグループと がある。整理番号34番のロシア正教守旧派 (オー ルド・ビリーバー)の家庭の家系図にも72人ほどの 人物が登場するが、そこでは実に多くの他民族が 観察される。ポーランド人が11名、リトアニア人が3 名、ユダヤ人が1名、タタール人(イスラム教徒)が1 名登場し、戦後生まれの世代では、とりわけポーラ ンド民族との混血が進んでいることが分かる。自 己意識の面でも、若い世代にあっては自分がリトア ニア人であるとの意識を持っている者も增えてき ている。しかしながら、戦前世代までは、ロシア正 
表5 家系図登場人物の民族分類表

\begin{tabular}{|c|c|c|c|c|c|c|c|c|c|c|c|c|}
\hline $\begin{array}{l}\text { 家庭 } \\
\text { 番号 }\end{array}$ & $\begin{array}{l}\text { 家族の民 } \\
\text { 族系列 }\end{array}$ & \begin{tabular}{|l|} 
登場人 \\
物総数 \\
(人)
\end{tabular} & $\begin{array}{l}\text { うちリ } \\
\text { トアニ } \\
\text { ア人 }\end{array}$ & $\begin{array}{l}\text { ポーラ } \\
\text { ンド人 }\end{array}$ & $\begin{array}{l}\text { ベラル } \\
\text { 一シ人 }\end{array}$ & $\begin{array}{l}\text { ロシア } \\
\text { 人正統 } \\
\text { 派 }\end{array}$ & $\begin{array}{l}\text { 正教オ } \\
\text { ールド } \\
\text { ビリー } \\
\text { バー派 }\end{array}$ & $\begin{array}{l}\text { タター } \\
\text { ル人 }\end{array}$ & $\begin{array}{l}\text { ユダヤ その他 } \\
\text { 人 }\end{array}$ & $\begin{array}{l}\text { 分類不 } \\
\text { 能 }\end{array}$ & $\begin{array}{l}\text { ポーラ } \\
\text { ンド移 } \\
\text { 住者 } \\
\text { (内数) }\end{array}$ & $\begin{array}{l}\text { 国外移住者 } \\
\text { (ポーランドとベラルーシ } \\
\text { を除く) } \\
\text { (内数) }\end{array}$ \\
\hline 1番 & ポーランド & 34 & 1 & 32 & & & & & & 1 & 1 & \\
\hline 2番 & ポーランド & 28 & & 28 & & & & & & & 4 & \\
\hline 3番 & ポーランド & 48 & 1 & 47 & & & & & & & 4 & \\
\hline 4番 & ポーランド & 27 & & 27 & & & & & & & & \\
\hline 5番 & ポーランド & 35 & 4 & 31 & & & & & & & 2 & 6 (アルゼンチン4名、米·加) \\
\hline 6番 & ポーランド & 58 & & 57 & 1 & & & & & & 7 & 10 (アルゼンチン6名、米4名) \\
\hline 7番 & ポーランド & 35 & & 35 & & & & & & & & \\
\hline 8番 & ポーランド & 63 & & 63 & & & & & & & 7 & \\
\hline 9番 & ポーランド & 27 & & 27 & & & & & & & 2 & 1 (米) \\
\hline 10番 & ポーランド & 53 & 3 & 50 & & & & & & & 7 & \\
\hline 11番 & ポーランド & 58 & 2 & 53 & 2 & 1 & & & & & 7 & \\
\hline 13番 & タタール & 37 & 1 & & & & & 36 & & & & \\
\hline 14番 & タタール & 66 & 1 & 1 & 1 & & & 63 & & & & \\
\hline 16番 & タタール & 63 & 1 & 6 & & & & 56 & & & 1 & 1 (米) \\
\hline 23番 & リトアニア & 41 & 38 & & & 3 & & & & & & \\
\hline 34番 & ロシア & 72 & 3 & 11 & 2 & 4 & 50 & 1 & 1 & & & 2 (米) \\
\hline 35番 & ベラルーシ & 42 & 8 & 5 & 27 & & 1 & & & 1 & & 7 (イスラエル) \\
\hline 46番 & ユダヤ & 46 & 2 & & & & & & 44 & & & \\
\hline
\end{tabular}

（注1）家系困における登場人物数は、単に名前と性別のみ判明したものは登場人物とはせず、宗教・経歷など何らかの追加的情報が得られた者のみを登 場人物として計算した。

（注2）「分類不能」とは、未成年者で、使用言語や宗教などの社会環境情報から人種を推定することができなかった場合を指す。多くは混血の児童であり、 その両親とも面談できなかった場合であり、祖父母も明確な情報を与えなかった場合が該当する。

教徒の守旧派の中だけで婚姻関係が成立している ことが確認された。特に、守旧派であれ、正統ロ シア正教であれ、これらはカトリックやプロテスタ ントと同一のキリスト教範疇に属し、神父はこれら 近似諸宗教をまたがる婚姻を認めていること、そ して婚姻後は、夫婦で異なる教会に通う例が観察 されたことに注意されたい。このように少数民族に あっては、近似宗教の他民族との混血が進んでお り、このことが、複数民族社会にあって、社会の融 合要因として極めて重要な役割を果たしているこ とが分かる。しかし、キリスト教とイスラム教、ある いはへブライ教とキリスト教というように、宗教間 のバリアーが高い場合には、民族が融合化して共 存することは困難であるという結論も推測できよ う。あるいはそれでも融合化する場合には民族と してのアイデンティティが失われるとも考えられる。

次に戦後にリトアニアに移住してきたベラルーシ 人の例をみてみよう。整理番号35番の家庭の場合、 1970年まではべラルーシに居住していたカトリック であり、主にベラルーシ人同士での婚姻関係が成 立していた。しかしリトアニア移住後は、ポーランド 女性(カトリック)と再婚している。子供はリトアニ
ア語小学校に通学し、リトアニア化の傾向が観察さ れる。しかし、宗教においては、圧倒的にカトリッ クであり、カトリックという同一宗教内での血縁関 係であると述べることができる。

最後に圧倒的な少数民族であるタタール人(イス ラム教徒)の家系図を見てみよう。タタール人はリ トアニア国内にモスク(イスラム教寺院)が3カ所し かない全くの少数民族である。整理番号16番の家 庭の家系図が示すとおり、タタール人同士の婚姻 傾向は極めて強い。戦前世代では、タタール人以 外の要因は、一人のポーランド人が登場するだけ である。しかし、このような家系にあっても戦後世 代になると、異教徒であるポーランド人やリトアニ ア人との結婚の事例が登場するようになる。ロシ ア人とタタール人との婚姻も観察された。タタール 民族においてはリトアニア社会の中でリトアニア化 の傾向が強く現れており、民族としての存続が危 惧されるほどである。

本稿では家系図を紹介する紙幅がないので、18 戸の家系図の登場人物一覧だけを表5に示そう。 基本的には同一民族内で婚姻関係が形成されてき ており、民族をまたがる婚姻の場合でも近似宗教 
間の婚姻が主であることが理解されよう。またポー ランド人家系の場合にはポーランドへの移住者が 多数見られたこと、さらにアメリカ大陸やイスラエル など国外移住者も多数みられたことに留意された い。なお、家系図から分かることであるが、人種を またがる婚姻関係は、ほとんどが第二次世界大戦 後に発生しており、社会主義政権による人種融合 政策がある程度は影響していることが想像される。 また家系図に書き込まれている生活史から明らか になるが、戦後の社会主義時代においても宗教に 対する弾压はなく、自由に教会に通えたと多くの 人が証言している。ただ一部の人においては、子 供の洗礼をこっそり自宅で行ったとの証言が得ら れた。

結論をまとめれば、婚姻関係の基本的規定要因 は宗教である。とりわけ同一宗教内であれば、人 種と言語が異なる婚姻であってもその成立に何ら の困難もない。またキリスト教同士であれば近似 宗教の異教徒との結婚に強い障害はない。最も結 婚の壁が厚いイスラム教徒ですら、異教徒と結婚 するようになっている。この点がリトアニアにおけ る民族共存に貢献していると考える。

\section{7.リトアニアにおける言語政策}

歴代リトアニア政府は基本的には個別民族言語 の保護政策をとってきた。すなわち、ロシア帝国 支配下にあった第一次世界大戦前にあってもロシ ア帝国政府は、ユダヤ人向けの国立小学校を各地 に設置してきた。また第一次世界大戦後にポーラ ンド領となったビリュニュース県においても、ユダ ヤ人小学校は存続したし、リトアニア人小学校もポ ーランド政府は設置していた。このような少数民族 の保護を目的とする言語政策は、戦後の社会主義 時代においても、また1991年以降の市場経済シス テムにおいても継続された。

個々の民族の言語を保護するということは、民 族の存続にかかわる重要な要因であり、この点が 艿かされると社会的危機が発生すると考えられる。 複数民族社会において、民族間の共存と社会の安 定を図るため、ロシア帝国政府 (1914年以前)もポ
ーランド政府 (1920－1939)もソ連政府 (1944— 1991）も、そして現在のリトアニア政府 (1991一)も 少数民族に対する言語保護政策をとらざるをえな かったと理解できる。表6は1995年の首都周辺部 での小中学校での教有言語統計を示す。人口比率 からするとロシア語使用の小中学校数が多いこと と、ポーランド語使用の小中学校数が少ないことが 分かる。ただし複数言語学級を持つ学校のほとん どがポーランド語クラスを持っていることを考虑に 入れると、ポーランド語教有を極端に冷遇している とは言えず、少数民族言語であるポーランド語も保 護されているといえよう。

ただし極小の少数民族であるタタール人に対し ては言語保護政策は適用されなかった。したがっ て、全員のタタール人がタタール語を知らず、アラ 一の神をたたえる短い言葉など少数の単語を知っ ているにすぎない。タタール人がクリミア半島から リトアニアに移住してきたのは14世紀からであり、 その当初から信仰の点を除いて、現地社会に同化 してきた。したがって、この100年で言語保護政策 がとられなかったからといって、社会的に大きな不 満は発生しない。

では、歴代の政府は少数民族に対して、言語保 護政策だけを適用してきたのであろうか。結論を

表6 ビリュニュース地方における初級小学校・基 本小学校・中等学校における教育言語の統計

\begin{tabular}{|l|rr|}
\hline & 1995年の学校数 & $\begin{array}{r}1995 \text { 年の児童数 } \\
\text { (構成比) }\end{array}$ \\
\hline リトアニア語学校 & 62 & $45.937(59.6 \%)$ \\
ロシア語学校 & 33 & $23.710(30.8 \%)$ \\
ポーランド語学校 & 5 & $7.270(9.4 \%)$ \\
ベラルーシ語学校 & 1 & $141(0.2 \%)$ \\
複数言語の学級を & & \\
持つ学校 & 12 & 該当せず \\
\hline
\end{tabular}

(注1) 複数言語の学校とは、例えば、リトアニア語グルーフのクラスとポ ーランド語グルーフのクラスの両方を用意してある学校を指す。このタイ フの学校に学ぶ児童数は、この表では、それぞれの学習言語に応して分類 され集計されている。

(注2)「初級小学校」とは6歳時入学の1年生から4年生までを対象とし、 「基本小学校」とは5 年生から9年生までを対象とする学校であり、共に義 務教育である。この両者の学校がーつの建物の中に併置されていることが 多い。

(注3) [中等学校」とは15歳か53年間を学引高校のことを指し、大学進学 資格が得られる。動きながら学ぶことが原則の瞕業学校は中等学校には含 まれない。

出所 : Vilnius Skaiciais, Vilniuaus Aspekrities Statisitikos Valdyba. Vilnius, 1996. p. 79(「ビリュニュース統計」ビリュニュー 統計局、1996) 
表7 ビリュニュース地方における大学7校にお ける教育言語の統計

\begin{tabular}{|l|cc|}
\hline & 1992 年の学生数 & 1995 年の学生数 \\
\hline リトアニア語 & 22,253 & 22.513 \\
ロシア語 & 2.076 & 653 \\
ポーランド語 & 176 & 164 \\
英語 & 0 & 163 \\
ベラルーシ語 & 22 & 30 \\
\hline
\end{tabular}

(注) 7大学の内訳は、最大がビリュニュース大学で、ついでビリュニュー ス工科大学、ついでヒリュニュース教育大学であり、あとはビリュニュー ス音楽大学、ビリュニュース警察大学など小規模大学。なお、リトアニア 語以外の少数言語が教育言語となっているのは、ビリュニュース教育大学 の教員養成課程のみと思われる。ポーランド語小学校の教員等を養成する ため。

出所 Vilnius Skaiciais, Vilniuaus Aspekrities Statisitikos Valdyba. Vilnius, 1996, p. 82 (「ビリュニュース統計」.ビリュニュース 統計局. 1996)

述べれば、民族の存続を条件づけるという意味で は彼らの母語の保護は行ってきたが、少数民族を 社会に同化させるためには、支配民族の言語も学 習させるという政策をとってきた。この点では戦間 期のポーランド政府もソ連政府もそして現在のリト アニア政府も同様である。戦間期のポーランド支 配下におけるビリュニュース県では、リトアニア語 小学校であってもリトアニア語以外にポーランド語 の授業があった。社会主義時代のソ連政府はポー ランド語小学校の設置を認めてきたが、小学校 2 年 からリトアニア語の授業も平行して開始され、小学 校5年からはロシア語の授業が開始された(外国語 授業の開始年齡については時代により若干異な る)。このようにしてポーランド人であってもリトア ニア話とロシア語が話せるトライ・リンガルの国民 が養成されてきた。さらに、男子の徴兵制度のもと に軍隊(ソ連軍)ではロシア語だけの世界となる。 これらのことは少数民族を社会の中に抱㩲してい く上で重要な役割を果たした。職場に採用された 少数民族が上司や同僚と意思疎通を四る上で、こ の支配民族言語（ロシア語とリトアニア語）の学留 政策は大きな役割を果たし、複数民族社会の平和 的共存におおいに役立った。

\section{8.少数民族の就業機会の平等性}

複数民族社会の安定を図る上で経済的平等が重 要であることは容易に想像できる。民族ごとに生 活水準が大きく異なる場合、社会的な軋軪が生じ るからである。そして経済的平等を達成するため
には就業機会の平等が保証されなければならな い。

リトアニアにおいては、この就業機会の平等性は 形式上は維持されている。採用に際して、少数民 族用の採用枠があったという証言は全く得られな かったが、それにもかかわらず就業に差別はなか ったと、ほとんどの人が語っていた。詳細は筆者 が既に発表した別稿に譲るが(吉野1990ならびに 1991）、社会主義時代における就業機会と出世の 可能性はもっぱら学歴によって決定されてきた。 本人の実力よりも本人の学歴がまず尊重され、そ の学歴に適合した職種とポストに配属された。こ のような制度のもとでは、民族の違いは経済的不 平等をもたらさない。

たしかに、多くの農民が証言するように、戦後の リトアニアでは、多くのコルホーズや工場で、ロシ アから派遣されてきたロシア人が所長や社長の地 位を占めた。しかし部長やブリガード長以下のポ ストでは、諸民族が平等に扱われていたと、多くの 人が証言している。また少数民族保護の象徴とし て、大臣などの要職に少数民族が登用される例も 数多く観察された。

では、少数民族がリトアニア社会の中で経済的 に全く平等の立場にいるかという点については、 言語政策の観点からもう少し深く考察しなければ ならない。リトアニア農村部のポーランド人の多く が貧困に喘いでいるという事実はどこに起因する のであろうか。それは中等教育と高等教有におけ る言語政策である。ポーランド語の中等学校(高校) はビリュニュース市内に2校しかなく、農村部には 全くなく、ポーランド人児童の多くが、普通高校に 進学しずらい状況に置かれている。また表7が示す ように、社会主義崩壊後は、大学の授業はりトアニ ア語だけで行われており、人学試験もリトアニア語 で行われているという現実がある。社会主義時代 であれば、ポーランド人高校生はロシア語で大学 受験ができ、あるいはモスクワ大学等への留学の 道もあったが、現在では、大卒資格を得るにはリト アニア語が必須となっている。

現在のリトアニア政府は、高等教有は完全にリト 
アニア語で行う方針を堅持しており、企業や省庁 での公用語もリトアニア語だけに限定している。以 前の公用語はロシア語とリトアニア語の双方であ り、議会議事録もロシア語で作成されていたが、 市場経済化のもとでは経済活動や行政における言 語は完全にリトアニア化されている。既に述べた ように就業機会は学歴で規定され民族差別はない という点においては少数民族の経済的平等性は形 式的に保証されているが、高等教有への進学可能 性という点を考慮に入れると、少数民族、とりわけ ポーランド人に対する実質的差別が発生してきて いると言えよう。

この点に関して、ポーランド人より一層の少数民 族であるロシア正教徒 (ロシア人・ベラルーシ人) やタタール人の方が、リトアニア化が進んでいるだ けに、経済的平等性は保証されているという皮肉 な結果が生じている。

\section{9.結語}

今後のリトアニアでは、各民族は信仰と家庭内 言語だけは民族的同一性を保持しつつ、しかし社 会的活動においてはリトアニア化していくという方 向が予想される。高所得を得るためには、社会生 活におけるリトアニア化は不可欠となっている。こ のようにして、単に形式上だけでなく、実質的にも 経済的平等性を維持していくことが複数民族の平 和的共存にとって不可欠であり、しかしこのことは 民族の独自性を薄めることも同時に意味する。

複数民族社会における民族共存の条件は、ア） 宗教の維持、イ) 言語の維持、ウ) 経済的平等性の 達成、の三つであると筆者は考える。この三条件 をすべて達成できない場合には、以下の三つの選 択肢のどれかを選ばなければならないだろう。

a) 少数民族が多数民族に吸収されていく道。これ はリトアニアにおけるタタール人が該当する。また ロシア正教オールドビリーバー派のロシア人もこ れに該当しつつある。

b) 民族ごとに自治区を設けて分住する道。ただし 現在のリトアニア政府はこの道は選択していない。 社会生活におけるリトアニア化により経済的平等を
達成して民族の共存を四る道を選択している。

c) 多数民族が警察力・軍事力で少数民族を支配す る道。現在のリトアニアではこの必要性は全くな い。

上記ア）、イ)、ウ）の三条件の同時達成という難 しい課題を現在のリトアニア社会は抱えているが、 とりあえず今までのところは、体制移行の中で平和 的に遂行されている。その最大の貢献要因は、民 族をまたがる婚姻関係の成立 (混血)であるという のが、筆者の結論である。

\section{【文献】}

Geertz(1973), Geertz, Clifford, The Interpretation of Cultures - selected essays by Clifford Geertz, New York. 1973。吉田禎吾訳.「文化の解釈学」, 岩 波書店, 1987。

Ginzburg(1966), Ginzburg, Carlo, I benandanti: stregoneria e culti agrari tra cinquecento e seicento. Torino, 1966. 竹山博英訳.「ペナンダンティ: 1617世紀における悪魔崇拝と農耕儀礼」, せりか書 房, 1986。

Ginzburg(1976), Ginzburg, Carlo, Il fomaggio e $i$ vermi - cosmo di un mugnaio del'500, Torino, 1976. 杉山光信訳,「チーズとうじ虫」, みすず書房, 1986。

Lewis(1961), Lewis, Oscar, The Children of Sanchez - autobiography of a Mexican family, New York, 1961. 柴田稳彦他訳,「サンチェスの子供た ち」, みすず書房, 1962。

吉野(1998), 吉野悦雄, 「微視的制度研究の試み一 比較経済システム分析の観点から一」, 研究年報 「経済学」(東北大学), 第59巻第4号, 1998, 23-35 頁。

Yoshino(1997), Yoshino, Etsuo, Polscy Chlopy w Dwudziestym Wieku - podejscie mikro-deskryptywne, Semper, Warszawa. 1997. （「十世紀にお 
リトアニアにおける複数民族共存の条件

けるポーランド農民一微視的記述接近一」, センペ ル社, 1997), 総339頁。

吉野(1993), 吉野悦雄編著「ポーランドの農業と農 民一グシトエフ村の研究一」,木鐸社, 1993。総548 頁。

吉野(1991), 吉野悦雄,「ポーランドの労働・日本の 労働上巻」, 日本労働研究機構, 1991, 総390頁。

吉野(1990), 吉野悦雄,「ポーランドにおける「社会 主義社会」の実質的解体」「経済研究」(一橋大学), 第41巻第4号, 289-297頁。

Znaniecki(1918-1920), Thomas, William and Florian Znaniecki, The Polish Peasant in Europe and America, Alfred and Knopf Inc. 1918-1920, (reprint: Octagon Books, 1974)。 
Conditions for Multi-ethnic Coexistence in Lithuania

Etsuo Yoshino

(University of Hokkaido)

\section{SUMMARY}

In 1996-7 the author secured direct interviews with 45 families in the Vilnius region of Lithuania. The methodology of this research depends on the micro-descriptive approach, which is shown in the author's book in Polish(see: Etsuo Yoshino, Polscy Chlopi w XX wieku, Semper, Warsaw, 1997)

In this research the author wrote down a family tree with every family and using this family tree the author analysed the structure of multiracial society in Lithuania from the following viewpoints: marriage, religion, language, education, emigration, vocation and income. Taking into account these factors the author reconstructed the life-history of every family.

General conditions of peaceful multiracialism consist of three points.

1) Guarantee of religion for every race.

2) Guarantee of language for every race.

3) Guarantee of equal income level for every race.

The third point is the most difficult condition for the Lithuanian government, because the changing manner of social life into Lithuanian style, i. e. Lithuanisation, became a necessary condition for higher income. If the government pursues the third point, then the identity of minorities may be lost, especially for the Tatars(Islam), the old-believer of the Orthodox Church and the Polish.

In Lithuania, in contrast to Bosnai-Hercegovina, after the second world war the marriage among different races is not an unusual case. The racial mixture can contribute, to a certain extent, the peaceful multiracialism with preservation of identity of minorities.

Key words : Lithuania

multiracialism

family tree 